\title{
Ozonation for source treatment of pharmaceuticals in hospital wastewater - ozone lifetime and required ozone dose
}

Hansen, Kamilla Marie Speht; Spiliotopoulou, Aikaterini; Chhetri, Ravi Kumar; Casas, Mònica Escolà; Bester, Kai; Andersen, Henrik Rasmus

\section{Published in:}

Chemical Engineering Journal

Link to article, DOI:

10.1016/j.cej.2016.01.027

Publication date:

2016

Document Version

Peer reviewed version

Link back to DTU Orbit

Citation (APA):

Hansen, K. M. S., Spiliotopoulou, A., Chhetri, R. K., Casas, M. E., Bester, K., \& Andersen, H. R. (2016).

Ozonation for source treatment of pharmaceuticals in hospital wastewater - ozone lifetime and required ozone dose. Chemical Engineering Journal, 290, 507-514. https://doi.org/10.1016/j.cej.2016.01.027

\section{General rights}

Copyright and moral rights for the publications made accessible in the public portal are retained by the authors and/or other copyright owners and it is a condition of accessing publications that users recognise and abide by the legal requirements associated with these rights.

- Users may download and print one copy of any publication from the public portal for the purpose of private study or research.

- You may not further distribute the material or use it for any profit-making activity or commercial gain

- You may freely distribute the URL identifying the publication in the public portal 


\section{Ozonation for source treatment of pharmaceuticals in hospital wastewater - ozone lifetime and required ozone dose}

Kamilla M. S. Hansen ${ }^{1}$, Aikaterini Spiliotopoulou ${ }^{2}$, Ravi Kumar Chhetri ${ }^{1}$, Mònica Escolà Casas $^{3}$, Kai Bester ${ }^{3}$,Henrik R. Andersen ${ }^{*}$

${ }^{1}$ Department of Environmental Engineering, Technical University of Denmark, Miljøvej 113, 2800 Kongens Lyngby, Denmark. *Corresponding author: Henrik@ndersen.dk

${ }^{2}$ Water ApS, Farum Gydevej 64, 3520 Farum, Denmark

${ }^{3}$ Department of Environmental Science, Aarhus University, Frederiksborgvej 399, 4000 Roskilde, Denmark

\section{Graphical abstract}
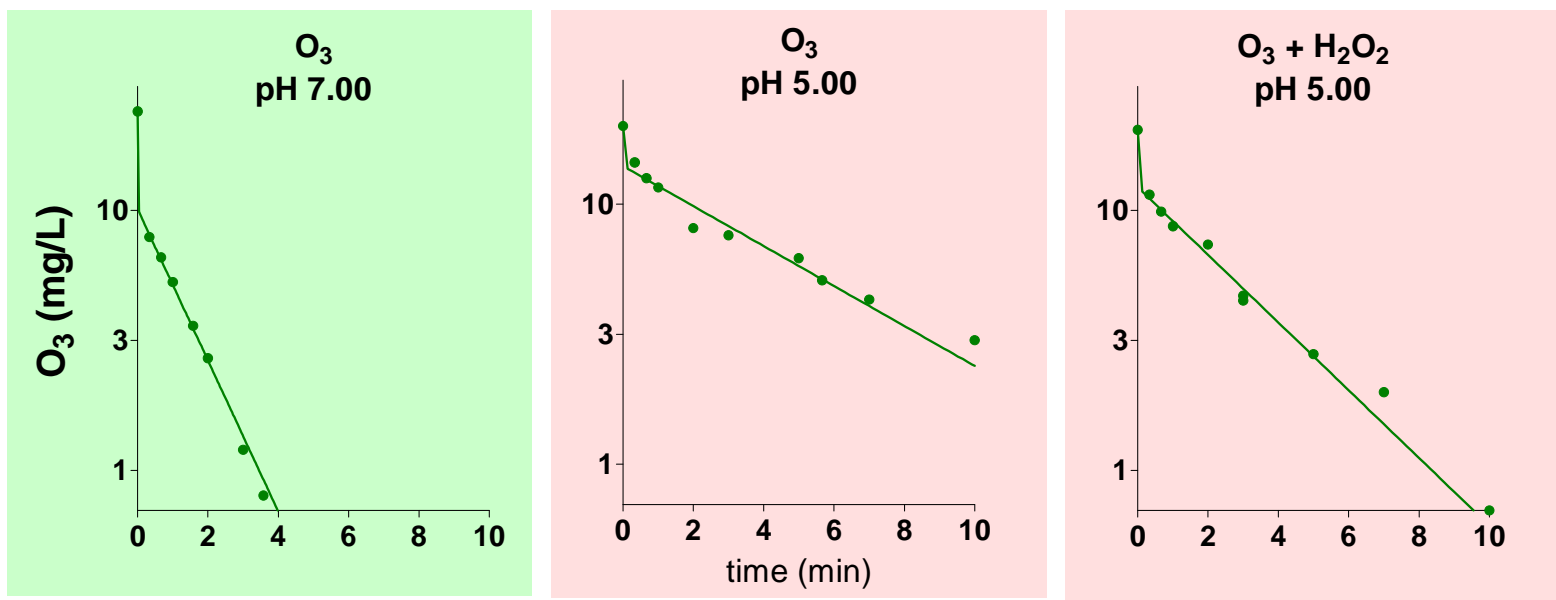

\section{Highlights:}

- Ozone dosage was determined for pharmaceuticals removal in hospital wastewater

- The ozone dosage required varied 2-fold with both DOC and $\mathrm{pH}$ experienced over time

- DOC normalized ozone dosage for $90 \%$ removal of 32 pharmaceuticals was determined

- At low pH, pharmaceuticals need less ozone while ozone lifetime increased to $20 \mathrm{~min}$

- $\mathrm{H}_{2} \mathrm{O}_{2}$ dosing shorten the ozone lifetime at low $\mathrm{pH}$ to 5 min similar to neutral $\mathrm{pH}$ 


\begin{abstract}
Ozonation aimed at removing pharmaceuticals was studied in an effluent from an experimental pilot system using staged Moving Bed Biofilm Reactor (MBBR) tanks for the optimal biological treatment of wastewater from a medical care unit of Aarhus University Hospital. Dissolved Organic Carbon (DOC) and $\mathrm{pH}$ in samples varied considerably, and the effect of these two parameters on ozone lifetime and the efficiency of ozone in removing pharmaceuticals were determined. The $\mathrm{pH}$ in the effluent varied from 5.0 to 9.0 resulting in approximately a doubling of the required ozone dose at the highest $\mathrm{pH}$ for each pharmaceutical. DOC varied from 6 to $20 \mathrm{mg}$ DOC/L. The ozone required for removing each pharmaceutical, varied linearly with DOC and thus, ozone doses normalized to DOC (specific ozone dosis) agreed between water samples (typically within 15\%). At neutral $\mathrm{pH}$ the specific ozone dose required to remove the easiest degradable pharmaceutical, sulfadiazine, was $0.50 \pm 0.04 \mathrm{mg}-\mathrm{O}_{3} / \mathrm{mg}-\mathrm{DOC}$ and the most recalcitrant, diatrizoic acid, required $4.7 \pm 0.6 \mathrm{mg}-\mathrm{O}_{3} / \mathrm{mg}$-DOC. The lifetime of ozone increased drastically in the higher end of the indicated dosage. At the lowest observed $\mathrm{pH}$ of 5.0, its lifetime was quadrupled to $20 \mathrm{~min}$ which influences the design of the reaction tank. The addition of $0.1 \mathrm{mg}-\mathrm{H}_{2} \mathrm{O}_{2}$ per $1 \mathrm{mg}-\mathrm{O}_{3}$ mitigated the prolonged lifetime without a corresponding influence in the pharmaceutical removal efficiency of ozone.
\end{abstract}

Keywords: Ozone, pharmaceuticals, hospital wastewater, DOC, pH, Lifetime. 


\section{Introduction}

The occurrence of pharmaceutical compounds in the aquatic environment is a known environmental issue, which cause a major concern as regards their potential impact on the environment and human health. Wastewater has been pointed out as the main route of entry of pharmaceuticals into the environment [1]. Pharmaceuticals utilized by humans are excreted either unchanged or as metabolites through feces or urine and transported with wastewater to WasteWater Treatment Plants (WWTPs ${ }^{1}$ ) where some pharmaceuticals are totally or partly removed before the effluent is discharged [2]. Although, the pharmaceuticals are found in low concentrations, they might adversely affect humans and living organisms [3].

Since several pharmaceuticals are poorly removed by conventional WWTP, various advanced tertiary treatments have been investigated [4]. The integration of ozone as an additional treatment step in the existing WWTP has become a widely accepted polishing technology for removing pharmaceuticals and other micro-pollutants in wastewater effluents [5-10]. Furthermore, treatment with ozone was found to be more cost effective than UV or $\mathrm{UV} / \mathrm{H}_{2} \mathrm{O}_{2}$ in the removal of estrogens in effluent from biologically treated wastewater [7,11] and it is more easily applied than activated carbon. During ozonation, micro-pollutants are oxidized either by a direct reaction with ozone (Eq. 1) or indirectly by the non-selective, highly reactive hydroxyl radicals (Eq. 4) [12]. Hydroxyl radicals are produced during the decomposition of ozone (Eq. 2) and the rate of decomposition increases with increasing $\mathrm{pH}$ [12]. Addition of $\mathrm{H}_{2} \mathrm{O}_{2}$ prior to ozonation, which is known as perozone, accelerates the decomposition of ozone to the non-selective hydroxyl radical (Eq. 3) [12]. Ozone efficiency against miscellaneous compounds is described by the reaction rate constants of micro-pollutants with these two, $\mathrm{k}_{\mathrm{O} 3}$ and $\mathrm{k}_{\mathrm{OH}}[13,14]$.

$$
\begin{array}{ll}
\mathrm{R}+\mathrm{O}_{3} \rightarrow \mathrm{R}_{\mathrm{ox}} & \text { Eq. } 1 \\
\mathrm{H}_{2} \mathrm{O}+\mathrm{O}_{3} \rightarrow \mathrm{O}_{2}+2 \mathrm{HO}^{\circ} & \text { Eq. } 2 \\
\mathrm{H}_{2} \mathrm{O}_{2}+2 \mathrm{O}_{3} \rightarrow 3 \mathrm{O}_{2}+2 \mathrm{HO}^{\circ} & \text { Eq. } 3 \\
\mathrm{R}+\mathrm{HO}^{\circ} \rightarrow \mathrm{R}_{\mathrm{ox}} & \text { Eq. } 4
\end{array}
$$

Wastewater from hospitals are often mixed with municipal wastewater and treated at the municipal WWTPs. Several studies have shown that the contribution of hospitals to the overall input of pharmaceuticals to the municipal WWTPs is minor [15-17]. Despite the debate on the importance of hospital wastewater as a significant point source for pharmaceuticals in scientific literature, Danish hospitals are required to make plans for a reduction in concentrations of pharmaceuticals occurring in their wastewater due to political interest in hospital wastewater.

If biological treatment (for example using activated sludge or biofilms) followed by ozonation is applied for point source treatment of micropollutants at a hospital, certain challenges can be envisaged in the water chemistry when compared with a system operation on municipal wastewater, owing to the lack of mixing with other sources of wastewater: Firstly, $\mathrm{pH}$ might systematically deviates more from neutral $\mathrm{pH}$ than the wastewater of the entire municipal system would, or it fluctuates considerably due to absence of mixing with many other sources. Additionally, a small source treatment system, intended for a single hospital building might not use denitrification for its biological treatment, as any nitrate released will be consumed in the sewer system. Thus, alkalinity in the water is consumed through the nitrification of ammonia and this might be particularly significant in hospital wastewater which is known to contain more reduced nitrogen than municipal

\footnotetext{
1 Abbreviations:

$\mathrm{DDO}_{3}$ : Decadic dose of ozone; required ozone dose needed to remove $90 \%$ of a pharmaceutical

$\mathrm{DO}_{3}$ : Delivered ozone dose

DOC: Dissolved organic carbon

MBBR: Moving bed biofilm reactor

WWTP: Wastewater treatment plant
} 
wastewater $[18,19]$. At lower $\mathrm{pH}$, ozone is converted slowly to hydroxyl radicals (HO; Eq. 2) and thus the lifetime increases for ozone. Secondly, the concentration of the matrix components in the effluent consuming ozone in competition with the targeted pharmaceuticals will inherently fluctuate due to single events in the hospital, which have proportionally more effect on the local treatment system than similar events that are averaged by dilution in a larger wastewater system prior to entering a municipal WWTP.

Thus, this work is aimed at quantifying the variation in ozone requirement necessary for the removal of pharmaceuticals in a biological pre-treated wastewater from a single medical section of a hospital which is caused by the smaller system. We addressed the special problem associated with the single source character majorly because the ozone dosage for removal of each pharmaceutical is influenced by greater DOC and $\mathrm{pH}$ variation. Experiments on the variations of each parameter are performed while determining the ozone kinetic and the ozone dosage required for removing a range of pharmaceuticals. Additionally, we investigated the extent of the expected increase in ozone lifetime at low $\mathrm{pH}$ and if it can be mitigated through the application of a small dose of hydrogen peroxide.

\section{Methods}

\subsection{Chemicals}

All pharmaceutical reference standards of analytical grade $(>98 \%)$ were purchased from different suppliers (Table S1 and [20]). A stock solution of the pharmaceuticals was prepared in methanol (Merck, Darmstadt, Germany). All other chemicals were purchased from Sigma-Aldrich Denmark ApS and were used as received. The experimental set-up for the ozonation was based on a $20 \mathrm{~g} / \mathrm{h}$ ozone generator from O3-Technology AB, Vellinge, Sweden, which was supplied with dry oxygen gas. To create an ozone stock solution, the generated ozone was dispersed through a diffuser in a collection bottle containing ultra-pure water which was immersed in an ice bath in order to increase ozone solubility. To further increase the solubility of the ozone a manometer and a valve were placed after the collection bottle and a pressure at 1.4 barG was established. Based on these experimental conditions, the concentration of ozone in the stock solution was between 70 and 90 $\mathrm{mg} / \mathrm{L}$.

\subsection{Quantifications}

\subsubsection{Determination of ozone concentration}

Ozone concentration was quantified using the indigo method [21]. The reagents used were $0.5 \mathrm{M}$ phosphate buffer at $\mathrm{pH} 2$ and $1.00 \mathrm{~g} / \mathrm{L}$ potassium indigotrisulfonate dissolved in $20 \mathrm{mM}$ phosphoric acid. For the ozone decomposition profile, the volumes from Bader and Hoigné [21] were downsized to fit into a $3 \mathrm{~mL}$ cuvette. Specifically, $0.100 \mathrm{~mL}$ indigotrisulfonate $(1.0 \mathrm{~g} / \mathrm{L})$ and 0.250 $\mathrm{mL}$ phosphate buffer $(0.5 \mathrm{M}$ at $\mathrm{pH} 2)$ were added to the cuvette. Ultra-pure water and sample were then added, so the total volume became $2.5 \mathrm{~mL}$. The quantity of sample and ultra-pure water was varied depending on the ozone concentration. The absorbance of the unreacted indigotrisulfonate was measured at $600 \mathrm{~nm}$. By comparing the absorbance of a blank with the sample and using $\Delta \mathrm{A}=$ $-200001 /(\mathrm{cm} \cdot \mathrm{mol}$ ozone added per L), the ozone concentration was determined.

The delivered ozone dose was determined by adding a sufficient amount of indigotrisulfonate and $10 \mathrm{~mL}$ phosphate buffer into $100 \mathrm{~mL}$ sample. For example, a water sample $(100 \mathrm{~mL})$ was ozonated with an ozone dose of $2 \mathrm{mg} / \mathrm{L}$. To determine the delivered ozone dose, $4.0 \mathrm{~mL}$ indigotrisulfoate (1.0 $\mathrm{g} / \mathrm{L}$ ) and $10 \mathrm{~mL}$ phosphate buffer were added into a $100 \mathrm{~mL}$ volumetric flask and it was filled to the mark with ultra-pure water and then poured into a glass bottle. The same amount of ozone stock 
solution was then added to the glass bottle as was added to the water sample. The absorbance of the unreacted indigotrisulfonate was measured at $600 \mathrm{~nm}$ and compared with the absorbance of a blank. The ozone dose was then determined using $\Delta \mathrm{A}=-200001 /(\mathrm{cm} \cdot \mathrm{mol}$ ozone added per $\mathrm{L})$.

\subsubsection{Dissolved organic carbon (DOC)}

A Shimadzu ASI-V UVC/Persulphate analyzer was utilized for the quantification of the nonvolatile organic carbon in the samples. Sample injection volume was $3.00 \mathrm{~mL}$ and a calibration curve with potassium hydrogen phthalate standards from $50-2000 \mu \mathrm{g} / \mathrm{L}$ was determined $\left(\mathrm{R}^{2}=\right.$ $0.9994)$. The method quantification limit is $50 \mu \mathrm{g} / \mathrm{L}$. From this point and onward, the non-volatile organic carbon results will be referred to as DOC.

\subsubsection{Hydrogen peroxide}

Hydrogen peroxide was analyzed by the colorimetric method using potassium titanium oxide oxalate which forms the yellow pertitanic acid complex in present of hydrogen peroxide. The colored complex is measured spectrophotometrically at $400 \mathrm{~nm}$ and the measuring range is $0.05-$ $90 \mathrm{mg}-\mathrm{H}_{2} \mathrm{O}_{2} / \mathrm{L}[22]$.

\subsubsection{Model compounds by GC-MS}

The method used for analysis of the model compounds is based on Hey et al. [23]. However, the derivatization procedure was changed according to Samaras et al. [24]. In brief, the sample was acidified by adding phosphate buffer $(5.4 \mathrm{M} ; 10 \mathrm{~mL}$ buffer/L sample) to $\mathrm{pH} 3$ and surrogate standard was added. Afterwards, the samples were extracted using Oasis ${ }^{\circledR} 3 \mathrm{cc}(60 \mathrm{mg}) \mathrm{SPE}$ columns (Waters, Denmark). The SPE columns were frozen before being transferred to a freeze dryer. When dry, the columns were eluted with $2 \mathrm{~mL}$ ethyl acetate which afterwards was reduced to approximately $100 \mu \mathrm{L}$ under a gentle steam of nitrogen. The samples were transferred to GC vial and then evaporated completely to dryness. Afterwards, $10 \mu \mathrm{L}$ anhydrous pyridine and $50 \mu \mathrm{L}$ N,Obis(trimethylsilyl) trifluoroacetamide with 1\% trimethylchlorosilane (BSTFA+TMCS, 99:1, Supelco 33155-U, Sigma Denmark) were added. The vials were capped and shaken for 1 min and heated in an oven at $70{ }^{\circ} \mathrm{C}$ for $30 \mathrm{~min}$. Finally, the pharmaceuticals were quantified by GC-MS (Agilent GC 6890N, MSD 5973N utilizing a CombiPAL from CTC analytics as auto sampler).

\subsubsection{Target pharmaceuticals by HPLC-MS/MS}

In $10 \mathrm{~mL}$ of sample from each treatment, $3.5 \mathrm{~mL}$ methanol was added and then placed in the freezer $\left(-20{ }^{\circ} \mathrm{C}\right)$ until the day of analysis. On the day of analysis, the samples were taken from the freezer, left to reach room temperature and homogenized. $900 \mu \mathrm{L}$ of sample were transferred to a HPLC vial and $100 \mu \mathrm{L}$ of internal standard was added. To ensure a particle-free injection in the HPLC-MS/MS, the samples were centrifuged for 10 minutes at $6000 \mathrm{rpm}$. The $50 \mu \mathrm{L}$ required for injection was taken $3 \mathrm{~mm}$ from bottom of the vial and analyzed by means of HPLC-MS/MS. The HPLC was equipped with a dual low-pressure mixing ternary-gradient system Ultimate 3000 from Dionex. The HPLC was operated with the following gradient elution of methanol and ultra-pure water, both containing $0.2 \%$ formic acid (v/v) on a Synergi-Polar column (Phenomenex, Torrance, California, USA). The mass spectrometer was an API 4000 (ABSciex, Framingham, MA, USA). Further details can be found in Escolà Casas et al. [20].

\subsection{Effluent from Moving Bed Biofilm Reactor}

A MBBR train was installed to treat a fraction of the wastewater from the oncology section of Aarhus University Hospital. The MBBR train consisted of three identical reactors of $3 \mathrm{~L}$ each connected in series (M1, M2 and M3). Each of the reactors contained 500 AnoxKaldnes $^{\mathrm{TM}} \mathrm{K} 5$ carriers (AnoxKaldnes, Lund, Sweden), which results in a filling ratio of $50 \%$. Mixing in each reactor was performed by aeration. Water was pumped in a flow of $0.50 \mathrm{~L} / \mathrm{h}$ through the MBBR train. 
The raw hospital wastewater was pumped through an $80 \mu \mathrm{m}$ filter (Amiat Water Systems, Bochum, Germany) using a mono-pump (Seepex, Hillerød, Denmark) into a $100 \mathrm{~L}$ container (H0) with cooling (temperature $15-18{ }^{\circ} \mathrm{C}$ ). The purpose of this container was to equalize the flow over the calendar day as very low flow was frequently observed at night in the wastewater pipe. From H0, the water was pumped to MBBR tank M1, using a peristaltic pump (Watson-Marlow, Ringsted, Denmark). Effluent was collected for different days and kept frozen $\left(-18{ }^{\circ} \mathrm{C}\right)$ until the day of experiment.

The general parameters of the wastewater, such as $\mathrm{pH}$, oxygen, COD, DOC and nitrification were measured regularly. More detailed description and result from the experimental operation can be found in Escolà Casas et al [25].

\subsection{Ozone lifetime in wastewater effluent}

A batch of effluent was divided into 5 different bottles and the $\mathrm{pH}$ was adjusted to $\mathrm{pH} 5.00,6.25$, 7.00, 7.75, and 9.00. Afterwards, the ozone stock solution was added into $50 \mathrm{~mL}$ subsamples, to deliver 0.7 or $1.4 \mathrm{mg}-\mathrm{O}_{3} / \mathrm{mg}$-DOC. Samples were taken at different reaction times to determine the ozone concentration. The delivered ozone dose was determined as described in Section 2.1. For experiments with ozone and hydrogen peroxide, the hydrogen peroxide $\left(0.1 \mathrm{mg}-\mathrm{H}_{2} \mathrm{O}_{2} / \mathrm{mg}-\mathrm{O}_{3}\right)$ was added prior to ozone addition at $\mathrm{pH} 5.00$ and $\mathrm{pH} 6.25$.

\subsection{Ozonation of effluent spiked with pharmaceuticals}

In order to determine the destruction of pharmaceuticals with increasing ozone doses, applied dosage experiments were performed. A batch of effluent was spiked with the pharmaceuticals $(10-$ $80 \mu \mathrm{g} / \mathrm{L}$ depending on the pharmaceutical) by adding the stock solution at the bottom of a clean glass bottle and evaporating the methanol. Afterwards, the effluent was added and stirred overnight at $15{ }^{\circ} \mathrm{C}$. The $\mathrm{pH}$ was adjusted to $\mathrm{pH} 7.00$ for the experiments with different DOC values and to $\mathrm{pH}$ $5.00,6.25,7.00,7.75$, and 9.00, respectively, for experiments aimed at investigating the $\mathrm{pH}$ effect. The spiked effluent was divided into smaller glass bottles, $100 \mathrm{~mL}$ in each. Different volumes of ozone stock solution were added to give nominal concentrations between 0.44 and $27 \mathrm{mg}-\mathrm{O}_{3} / \mathrm{L}$ and each treatment dosage was made in duplicates. The bottles were then left to stand at $15^{\circ} \mathrm{C}$ for at least $1 \mathrm{~h}$, to allow ozone reactions to proceed until completion.

In the experiment with hydrogen peroxide addition, the hydrogen peroxide was added prior to the addition of ozone.

\subsection{Data treatment}

In order to determine the efficiency of ozone in the removal of the investigated pharmaceuticals, the ozone dose that achieved $90 \%$ removal of each pharmaceutical was determined. This was done by fitting the obtained removal of a pharmaceutical at each ozone dose in each effluent with Equation 5:

$$
\frac{C}{C_{0}}=10^{-\left(\frac{D O_{3}}{D D O_{3}}\right)}(\text { eq. } 5)
$$

The equation describes the remaining pharmaceutical $(\mathrm{C})$ in relation to its initial concentration $\left(\mathrm{C}_{0}\right)$ after its reaction with a specific Delivered Ozone dose $\left(\mathrm{DO}_{3}\right)$ with $\mathrm{DDO}_{3}$ (Decadic Dose of Ozone) as compound specific constant describing the required ozone dose needed to remove $90 \%$ of the respective pharmaceutical. This is based on the fact that the decomposition of ozone is determined by the effluent matrix and it is independent of the pharmaceutical concentration. 
Equation 5 has previously been used to characterize the efficiency of ozone treatment for removal of estrogenic compounds [7] and active pharmaceutical ingredients [10].

The $\mathrm{DDO}_{3}$ figures as a constant in Equation 5, which allows for the determination of the standard error of $\mathrm{DDO}_{3}$ directly through curve fitting. All curve fitting was conducted in Prism 5, GraphPad.

\section{Results and discussion}

During the experimental running of the MBBR train, $\mathrm{pH}$ in all the reactors was measured twice a week (Figure 1). The DOC was measured approximately every week for inlet (H0) and outlet (M3). The effluent from the MBBR train varied in DOC concentration and $\mathrm{pH}$ value. This high variation may a result of sampling very close to the source without dilution with water from other sources.

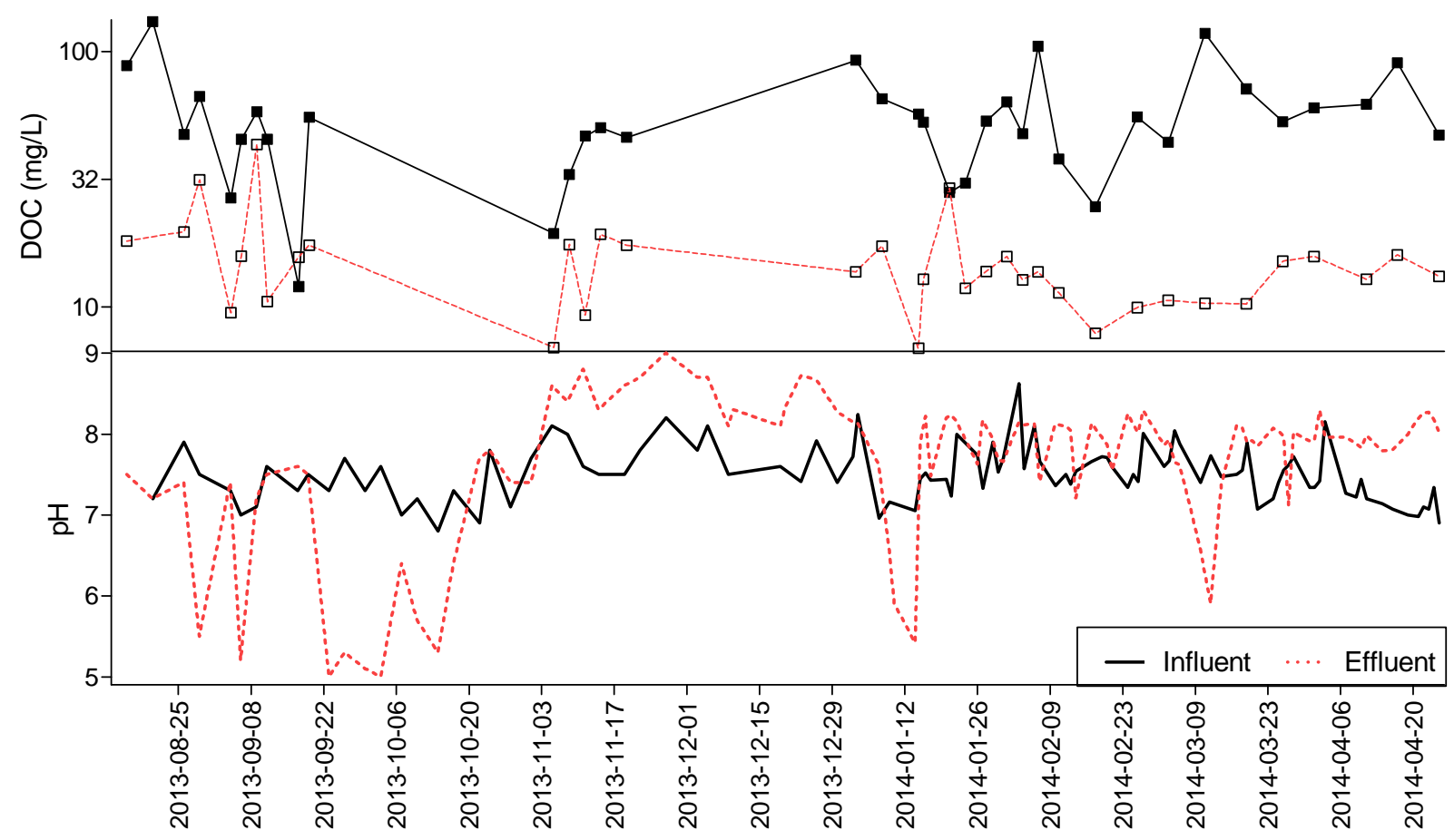

Figure 1 Measured $\mathrm{pH}$ and DOC during the period with experimental run of the MBBR train.

\subsection{Effect of DOC on required ozone dosage for pharmaceuticals removal}

Pharmaceuticals were spiked to effluent water from the MBBR train with different DOC levels. The samples were treated with ozone to evaluate the removal efficiencies. The measured concentration of pharmaceuticals with the different ozone treatment is normalized to the initial concentration and plotted as a function of the $\mathrm{DO}_{3}$. The results from one of the effluents can be seen in Figure 2, while the rest can be found in Figure S1-S2 in SI. Generally, the removal of the compounds increases with increasing ozone dose, while different reactivity of ozone towards different compounds in the same effluent sample was observed. Furthermore, the removal of each compound from different effluent samples of the same source treated with the same ozone dose differed considerably. This is in accordance with previous findings $[6,7,10,26]$. 

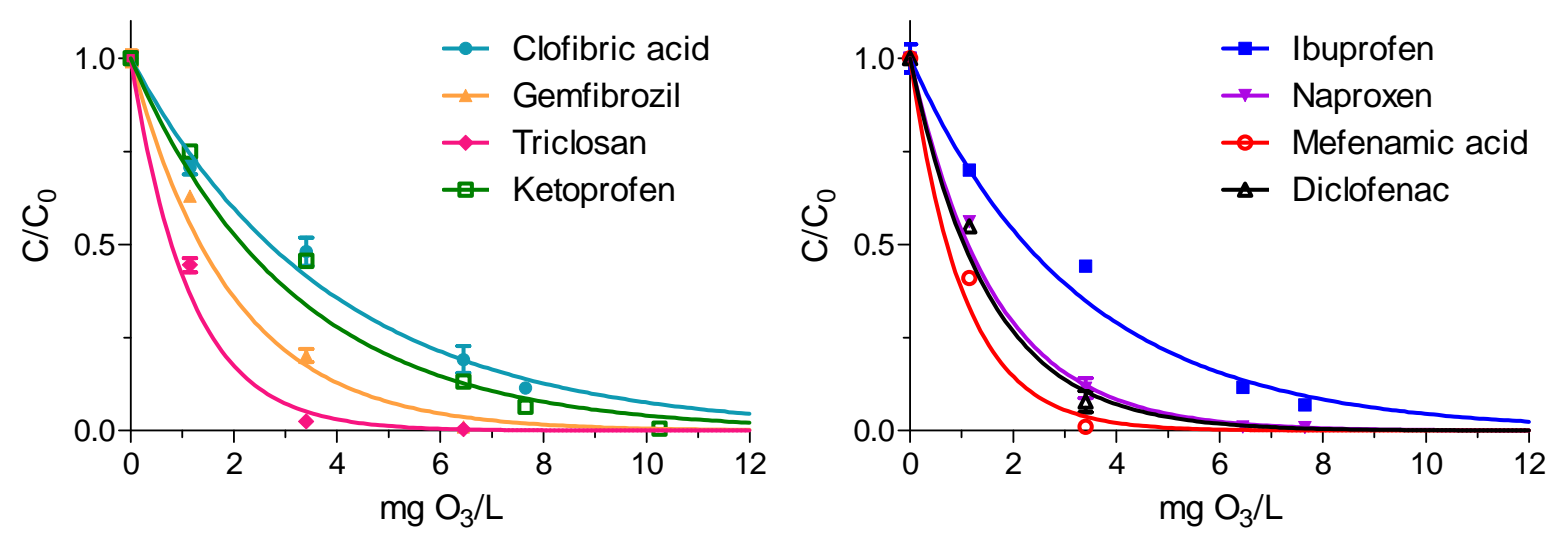

Figure 2 An example of removal of pharmaceuticals by ozone in effluent from the MBBR system $\left(\mathrm{DOC}=7.3 \mathrm{mg} / \mathrm{L}, \mathrm{pH} 7, \mathrm{~T}=15^{\circ} \mathrm{C}\right)$.

In order to determine the ozone dose that is required to achieve $90 \%$ removal of each pharmaceutical, the data in Figure 2 were fitted with Equation 5. The obtained $\mathrm{DDO}_{3}$ increases with increasing DOC for all the investigated compounds (Table 1). Buffle et al. [27] have found that DOC is crucial for ozone exposure and that the ozone dose should be normalized with DOC for comparison of different water. Thus, the delivered ozone doses were normalized with DOC and the specific $\mathrm{DDO}_{3}$ was determined. The specific $\mathrm{DDO}_{3}$ are given in Table 1 . The variation of the specific $\mathrm{DDO}_{3}$ for the different effluents is small and the average has been calculated. The specific $\mathrm{DDO}_{3}$ varies from $0.50 \pm 0.04 \mathrm{mg}-\mathrm{O}_{3} / \mathrm{mg}$-DOC for the most easily degradable compound (sulfadiazine) to $4.7 \pm 0.6 \mathrm{mg}-\mathrm{O}_{3} / \mathrm{mg}-\mathrm{DOC}$ for the most recalcitrant compound (diatrizoic acid) (Table 1). This variation is due to the different molecular structures of the investigated compounds. Some react fast with ozone, while others react slower and then the reaction with hydroxyl radicals will be important for the degradation of a compound [10,26,28]. 


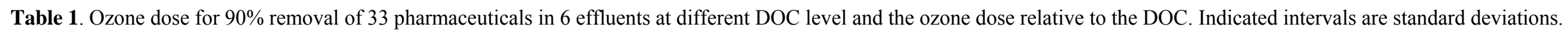

\begin{tabular}{|c|c|c|c|c|c|c|c|c|c|c|c|c|c|c|c|c|c|c|c|c|c|c|}
\hline \multirow[b]{2}{*}{ DOC level (mg/L) } & \multicolumn{10}{|c|}{$\mathrm{DDO}_{3}$} & \multicolumn{10}{|c|}{$\mathrm{DDO}_{3} / \mathrm{DOC}$} & \multirow{2}{*}{\multicolumn{2}{|c|}{ Average }} \\
\hline & 5.6 & & 7.3 & & 13 & & 16 & & 18 & & 5.6 & & 7.3 & & 13 & & 16 & & 18 & & & \\
\hline \multicolumn{23}{|c|}{ Model compounds } \\
\hline Triclosan & 3.4 & \pm 0.2 & 2.6 & \pm 0.2 & 5.6 & \pm 0.5 & 7.0 & \pm 0.6 & 6.9 & \pm 0.6 & 0.60 & \pm 0.04 & 0.36 & \pm 0.03 & 0.43 & \pm 0.04 & 0.44 & \pm 0.04 & 0.38 & \pm 0.04 & 0.52 & \pm 0.10 \\
\hline Mefenamic acid & 4.1 & \pm 0.3 & 2.4 & \pm 0.2 & 5.4 & \pm 0.5 & 7.1 & \pm 0.8 & 6.5 & \pm 0.7 & 0.74 & \pm 0.06 & 0.33 & \pm 0.03 & 0.41 & \pm 0.04 & 0.45 & \pm 0.05 & 0.36 & \pm 0.04 & 0.53 & \pm 0.16 \\
\hline Diclofenac & 4.6 & \pm 0.4 & 3.5 & \pm 0.3 & 7.5 & \pm 0.8 & 8.9 & \pm 0.8 & 8.3 & \pm 1.5 & 0.82 & \pm 0.07 & 0.48 & \pm 0.04 & 0.58 & \pm 0.06 & 0.56 & \pm 0.05 & 0.46 & \pm 0.08 & 0.58 & \pm 0.14 \\
\hline Naproxen & 4.6 & \pm 0.3 & 3.7 & \pm 0.1 & 7.7 & \pm 0.6 & 10 & \pm 1 & 14 & \pm 2 & 0.81 & \pm 0.06 & 0.51 & \pm 0.02 & 0.60 & \pm 0.04 & 0.63 & \pm 0.04 & 0.76 & \pm 0.09 & 0.69 & \pm 0.12 \\
\hline Gemfibrozil & 5.5 & \pm 0.4 & 4.5 & \pm 0.3 & 11 & \pm 1 & 14 & \pm 1 & 11 & \pm 1 & 1.0 & \pm 0.1 & 0.62 & \pm 0.04 & 0.85 & \pm 0.05 & 0.86 & \pm 0.04 & 0.60 & \pm 0.05 & 0.80 & \pm 0.17 \\
\hline Ketoprofen & 5.7 & \pm 0.3 & 7.2 & \pm 0.4 & 14 & \pm 1 & 19 & \pm 2 & 18 & \pm 2 & 1.0 & \pm 0.1 & 1.0 & \pm 0.1 & 1.1 & \pm 0.1 & 1.2 & \pm 0.1 & 1.0 & \pm 0.1 & 1.2 & \pm 0.1 \\
\hline Ibuprofen & 6.6 & \pm 0.3 & 7.5 & \pm 0.4 & 16 & \pm 2 & 24 & \pm 1 & 22 & \pm 2 & 1.2 & \pm 0.1 & 1.0 & \pm 0.1 & 1.2 & \pm 0.1 & 1.5 & \pm 0.1 & 1.2 & \pm 0.1 & 1.3 & \pm 0.2 \\
\hline Clofibric acid & 6.7 & \pm 0.3 & 8.9 & \pm 0.4 & 17 & \pm 1 & 30 & \pm 4 & 23 & \pm 3 & 1.2 & \pm 0.1 & 1.2 & \pm 0.1 & 1.3 & \pm 0.1 & 1.9 & \pm 0.2 & 1.3 & \pm 0.1 & 1.5 & \pm 0.3 \\
\hline \multicolumn{23}{|c|}{ Target pharmaceuticals } \\
\hline Sulfadiazine & & & 3.3 & \pm 0.3 & 6.9 & \pm 0.8 & 8.2 & \pm 0.9 & & & & & 0.45 & \pm 0.04 & 0.54 & \pm 0.06 & 0.51 & \pm 0.06 & & & 0.50 & \pm 0.04 \\
\hline Sulfamethoxazole & & & 3.7 & \pm 0.4 & 7.0 & \pm 0.9 & 8.4 & \pm 1.1 & & & & & 0.51 & \pm 0.05 & 0.54 & \pm 0.07 & 0.52 & \pm 0.07 & & & 0.52 & \pm 0.02 \\
\hline Sulfamethizole & & & 3.9 & \pm 0.4 & 7.0 & \pm 0.6 & 7.9 & \pm 0.8 & & & & & 0.55 & \pm 0.06 & 0.54 & \pm 0.05 & 0.49 & \pm 0.05 & & & 0.52 & \pm 0.03 \\
\hline Diclofenac & & & 3.7 & \pm 0.3 & 7.3 & \pm 0.6 & 8.7 & \pm 0.8 & & & & & 0.51 & \pm 0.05 & 0.57 & \pm 0.05 & 0.54 & \pm 0.05 & & & 0.54 & \pm 0.03 \\
\hline Trimethoprim & & & 3.9 & \pm 0.4 & 7.3 & \pm 0.7 & 8.7 & \pm 0.9 & & & & & 0.55 & \pm 0.06 & 0.57 & \pm 0.06 & 0.54 & \pm 0.06 & & & 0.55 & \pm 0.01 \\
\hline Carbamazepine & & & 4.1 & \pm 0.4 & 7.7 & \pm 0.8 & 9.2 & \pm 1.0 & & & & & 0.57 & \pm 0.06 & 0.60 & \pm 0.06 & 0.57 & \pm 0.06 & & & 0.58 & \pm 0.02 \\
\hline Propranol & & & 4.1 & \pm 0.4 & 8.1 & \pm 0.7 & 9.6 & \pm 0.8 & & & & & 0.57 & \pm 0.06 & 0.63 & \pm 0.05 & 0.59 & \pm 0.05 & & & 0.60 & \pm 0.03 \\
\hline Sotalol & & & 4.6 & \pm 0.3 & 8.8 & \pm 0.7 & 10 & \pm 1 & & & & & 0.63 & \pm 0.04 & 0.68 & \pm 0.05 & 0.65 & \pm 0.05 & & & 0.65 & \pm 0.03 \\
\hline Roxithromycin & & & 5.0 & \pm 0.4 & 10 & \pm 1 & 12 & \pm 1 & & & & & 0.69 & \pm 0.06 & 0.78 & \pm 0.07 & 0.74 & \pm 0.07 & & & 0.74 & \pm 0.04 \\
\hline Clarithromycin & & & 5.1 & \pm 0.6 & 10 & \pm 1 & 12 & \pm 2 & & & & & 0.70 & \pm 0.08 & 0.79 & \pm 0.10 & 0.75 & \pm 0.09 & & & 0.75 & \pm 0.04 \\
\hline Phenazone & & & 5.2 & \pm 0.5 & 11 & \pm 1 & 13 & \pm 1 & & & & & 0.72 & \pm 0.07 & 0.82 & \pm 0.09 & 0.77 & \pm 0.09 & & & 0.77 & \pm 0.05 \\
\hline Ciprofloxacin & & & 4.8 & \pm 0.3 & 12 & \pm 2 & 14 & \pm 2 & & & & & 0.66 & \pm 0.05 & 0.91 & \pm 0.16 & 0.86 & \pm 0.15 & & & 0.81 & \pm 0.13 \\
\hline Clindamycin & & & 5.2 & \pm 0.3 & 12 & \pm 1 & 14 & \pm 1 & & & & & 0.72 & \pm 0.05 & 0.90 & \pm 0.07 & 0.85 & \pm 0.06 & & & 0.82 & \pm 0.09 \\
\hline Metoprolol & & & 5.6 & \pm 0.5 & 13 & \pm 2 & 15 & \pm 3 & & & & & 0.77 & \pm 0.08 & 1.0 & \pm 0.1 & 0.90 & \pm 0.16 & & & 0.89 & \pm 0.12 \\
\hline Tramadol & & & 6.2 & \pm 0.7 & 14 & \pm 2 & 16 & \pm 2 & & & & & 0.85 & \pm 0.10 & 1.1 & \pm 0.1 & 1.0 & \pm 0.1 & & & 0.97 & \pm 0.10 \\
\hline Ac-Sulfadiazine & & & 6.8 & \pm 0.4 & 14 & \pm 2 & 15 & \pm 2 & & & & & 0.93 & \pm 0.06 & 1.1 & \pm 0.1 & 0.94 & \pm 0.12 & & & 0.98 & \pm 0.08 \\
\hline Citalopram & & & 7.0 & \pm 0.8 & 14 & \pm 1 & 16 & \pm 1 & & & & & 0.96 & \pm 0.11 & 1.0 & \pm 0.1 & 0.99 & \pm 0.08 & & & 1.0 & \pm 0.0 \\
\hline Atenolol & & & 6.8 & \pm 0.5 & 16 & \pm 2 & 17 & \pm 3 & & & & & 0.94 & \pm 0.07 & 1.2 & \pm 0.2 & 1.1 & \pm 0.2 & & & 1.1 & \pm 0.1 \\
\hline Ibuprofen & & & 6.8 & \pm 0.5 & 20 & \pm 3 & 23 & \pm 3 & & & & & 0.94 & \pm 0.08 & 1.5 & \pm 0.2 & 1.4 & \pm 0.2 & & & 1.3 & \pm 0.3 \\
\hline Venlafaxine & & & 8.0 & \pm 0.7 & 20 & \pm 3 & 24 & \pm 4 & & & & & 1.1 & \pm 0.1 & 1.6 & \pm 0.2 & 1.5 & \pm 0.2 & & & 1.4 & \pm 0.2 \\
\hline Iopromide & & & 13 & \pm 1 & 23 & \pm 2 & 25 & \pm 2 & & & & & 1.8 & \pm 0.1 & 1.8 & \pm 0.1 & 1.5 & \pm 0.1 & & & 1.7 & \pm 0.1 \\
\hline Iohexol & & & 14 & \pm 1 & 25 & \pm 2 & 27 & \pm 2 & & & & & 1.9 & \pm 0.1 & 1.9 & \pm 0.1 & 1.6 & \pm 0.1 & & & 1.8 & \pm 0.1 \\
\hline Iomeprol & & & 15 & \pm 1 & 25 & \pm 2 & 27 & \pm 2 & & & & & 2.1 & \pm 0.1 & 1.9 & \pm 0.1 & 1.6 & \pm 0.1 & & & 1.9 & \pm 0.2 \\
\hline Iopamidol & & & 19 & \pm 1 & 35 & \pm 2 & 38 & \pm 2 & & & & & 2.6 & \pm 0.2 & 2.7 & \pm 0.1 & 2.3 & \pm 0.1 & & & 2.6 & \pm 0.2 \\
\hline Diatrizoic acid & & & 38 & \pm 4 & 61 & \pm 5 & 66 & \pm 5 & & & & & 5.2 & \pm 0.5 & 4.7 & \pm 0.4 & 4.1 & \pm 0.3 & & & 4.7 & \pm 0.6 \\
\hline
\end{tabular}




\subsection{Decomposition of ozone at different $\mathrm{pH}$}

It is well known that the decomposition of ozone is $\mathrm{pH}$ dependent [12]. A significant change in the ozone lifetime would affect the required size of the reaction tank for the ozonation. Thus, the decomposition of ozone in wastewater effluent at different $\mathrm{pH}$ values was investigated. As seen in Figure 3, a rapid decrease in ozone concentration was observed within the first 20 seconds. The investigation of ozone concentration within the first 20 seconds (initial phase) requires specialized equipment as used by Buffle et al. [29]. These authors discovered that the ozone decomposition in the initial phase followed higher-order kinetics while the second phase $(>20 \mathrm{sec})$ followed first order kinetic [29]. Our results also show a first order kinetic for ozone decomposition (Figure 3). Furthermore, the ozone decomposition increases with increasing $\mathrm{pH}$. This means that an ozone dose at $10 \mathrm{mg} / \mathrm{L}$ could be detected until $3 \mathrm{~min}$ at $\mathrm{pH} 5.00$, while at $\mathrm{pH} 6.25$ and 7.00 lifetime was reduced

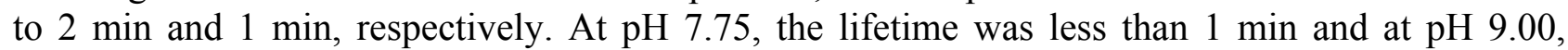
lifetime was less than 20 seconds. When a higher ozone dose $(20 \mathrm{mg} / \mathrm{L})$ was added, the lifetime was increased from $3 \mathrm{~min}$ to $20 \mathrm{~min}$ at $\mathrm{pH} 5.00$. However, at $\mathrm{pH} 6.25$ the lifetime was halved (10 min) and at $\mathrm{pH} 7.00$ the lifetime was again halved (5 min).

Besides $\mathrm{pH}$, the ozone dose affects the rate constants for the first order decomposition (rate constants are not shown). This confirms previous results where a decrease in rate constants with increasing ozone dose was found [30].
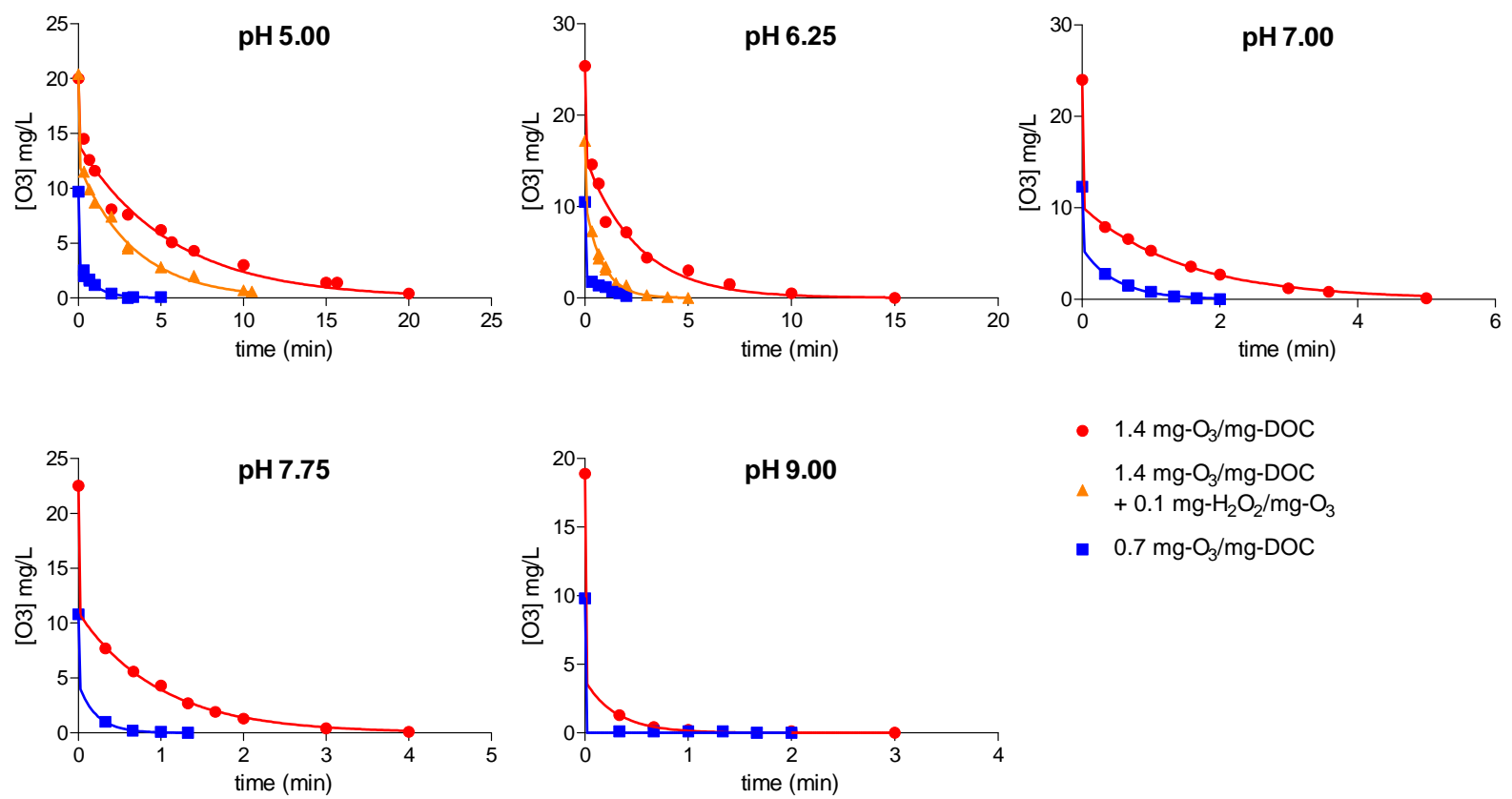

Figure 3 Ozone lifetime in effluent from MBBR $\left(\mathrm{DOC}=18 \mathrm{mg} / \mathrm{L}\right.$, temperature $\left.=15{ }^{\circ} \mathrm{C}\right)$ with two different initial concentrations of ozone at different $\mathrm{pH}$. At $\mathrm{pH} 5.00$ and 6.25 hydrogen peroxide was added prior to ozonation as well.

\subsection{Effect of $\mathrm{pH}$ on removal of pharmaceuticals}

Ozonation of wastewater effluent adjusted to different $\mathrm{pH}$ levels was used to investigate the effect of $\mathrm{pH}$ on ozone's efficiency to for the removal of the model compounds. The concentration profiles of the remaining pharmaceuticals at different ozone doses can be seen for the eight model compounds in Figure S4 alongside the resulting required ozone estimate. It was discovered that 
even though the ozone lifetime was short at $\mathrm{pH} 7.75$ and $\mathrm{pH} 9.00$, a removal of the eight model compounds was obtained. This supports the findings by Buffle et al. [29] where removal of some pharmaceuticals was calculated based on ozone and hydroxyl radical exposure and the second order rate constants and significant removal could be predicted even when ozone is decomposed within the first $20 \mathrm{sec}$.

At each $\mathrm{pH}$ level, the $\mathrm{DDO}_{3}$ value was determined for each pharmaceutical. In Figure 4, the $\mathrm{DDO}_{3}$ is plotted as a function of $\mathrm{pH}$ value. The $\mathrm{DDO}_{3}$ increases with increasing $\mathrm{pH}$ which means that a higher ozone dose is needed to remove the same amount of pharmaceutical when $\mathrm{pH}$ increases. A straight line was fitted to the data and the $\mathrm{R}^{2}$ was higher than 0.82 for all the compounds except for naproxen $\left(\mathrm{R}^{2}=0.4005\right)$. The $\mathrm{DDO}_{3}$ for the compounds which require high ozone dose to be removed (ibuprofen and clofibric acid), is the most affected by $\mathrm{pH}$.

Ozone is most reactive with compounds with high electron density [12,14]. However, a compound's reactivity towards ozone is affected by its speciation [31,32]. For all the investigated model compounds, the $\mathrm{pKa}$ is below 5 except for triclosan ( $\mathrm{pKa}=7.9$ [33]) and dissociation is not expected to have an effect on the difference in the obtained removal. In wastewater ozonation the removal of micropollutants is dependent on the ozone contact time and the reaction with ozone derived hydroxyl radicals which are both dependent on the water quality parameters DOC and $\mathrm{pH}$ and not on the concentration of the micropollutant as the ozone consumption by reaction with the micropollutant is insignificant compared to the reaction with DOC (ng/L versus $\mathrm{mg} / \mathrm{L}$ ). Thus with increased $\mathrm{pH}$ which shorter ozone lifetime relatively less removal of pharmaceutical are observed. Correspondingly a higher ozone dose is needed to obtain $90 \%$ removal.
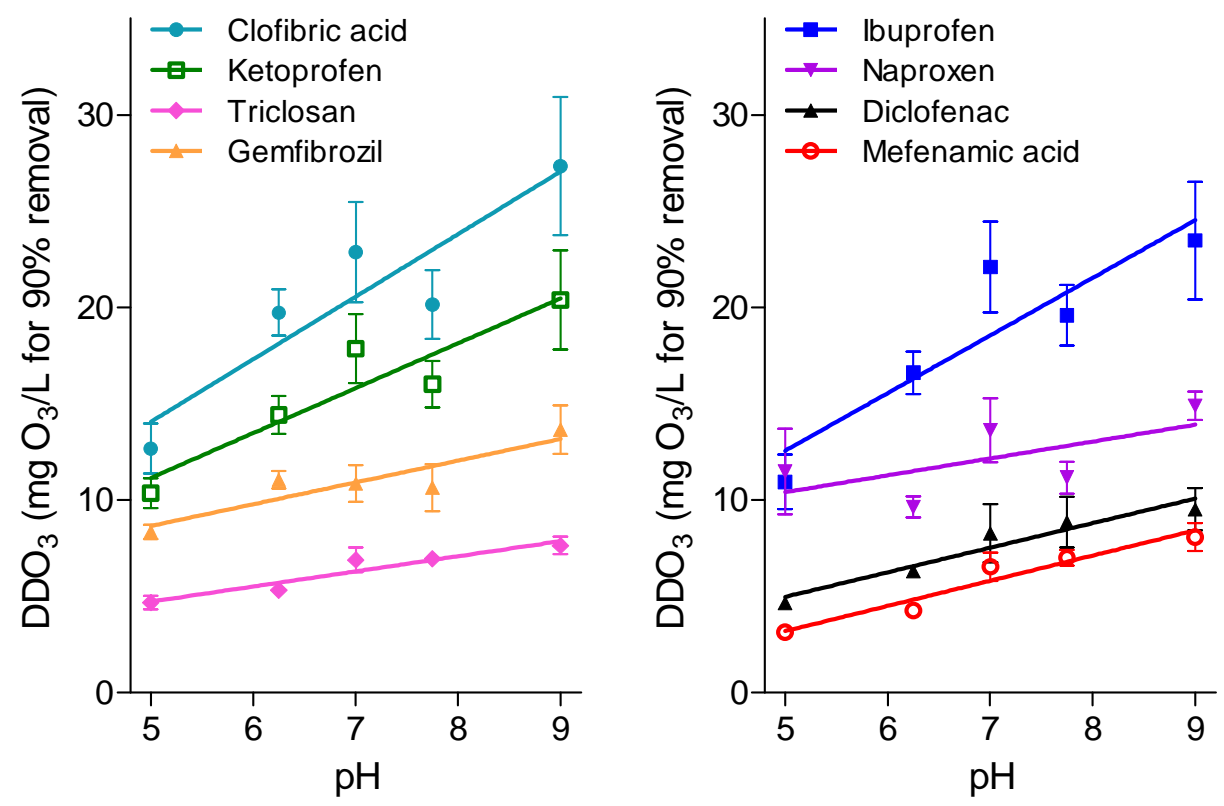

Figure 4 Decadic dose of ozone $\left(\mathrm{DDO}_{3}\right)$ for the eight model compounds at different $\mathrm{pH}$ values $\left(\mathrm{DOC}=18 \mathrm{mg} / \mathrm{L}, \mathrm{T}=15^{\circ} \mathrm{C}\right)$. Error bars represent the standard error.

\subsection{Catalytic activation of ozone by hydrogen peroxide}

In order to remove recalcitrant pharmaceuticals, a high ozone dose is necessary. In some situations, the $\mathrm{pH}$ value in wastewater effluent is low, which causes long lifetime of ozone and thus, a long resident time after ozone addition is needed to avoid emission of ozone. In such a case, the ozone 
lifetime can be reduced by the addition of hydrogen peroxide, which catalyzes the decomposition of ozone to hydroxyl radicals (Eq. 3). Previous investigations of hydrogen peroxide/ozone as an advanced oxidation of pharmaceuticals have used mass ratios in the range of $0.3-1[9,34]$, but mass ratios as high as $3.5\left(\mathrm{H}_{2} \mathrm{O}_{2} / \mathrm{O}_{3}\right)$ have been used for bromate inhibition during the ozonation of drinking water [35]. At very high $\mathrm{H}_{2} \mathrm{O}_{2} / \mathrm{O}_{3}$ ratios, the lifetime of ozone is very low, while according to Hey et al. [36], the addition of hydrogen peroxide at $0.1 \mathrm{mg}-\mathrm{H}_{2} \mathrm{O}_{2} / \mathrm{mg}-\mathrm{O}_{3}$ at $\mathrm{pH} 6$ decreased the lifetime of ozone to be similar with that found for ozone at $\mathrm{pH} 8$. As seen in Figure 3, the lifetime of ozone is reduced from $20 \mathrm{~min}$ to $10 \mathrm{~min}$ at $\mathrm{pH} 5.00$ and from $10 \mathrm{~min}$ to $3 \mathrm{~min}$ at $\mathrm{pH} 6.25$ by the addition of $0.1 \mathrm{mg}$ hydrogen peroxide per $\mathrm{mg}$ of ozone.

Since the pharmaceuticals are removed by either direct reaction with ozone or hydroxyl radicals (eq. 1 and 4), the addition of hydrogen peroxide could affect the degree of elimination of some pharmaceuticals. Ternes et al. [9] observed a slightly increased removal of X-ray contrast media, while Venditti et al. [37] observed a decreased removal during the addition of hydrogen peroxide. In our study, there was observed no effect of hydrogen peroxide addition on removal of the 8 model compound (Figure 4). Thus, it seemed that low concentration of hydrogen peroxide can be added without a corresponding change in the effectiveness of the removal of pharmaceuticals.
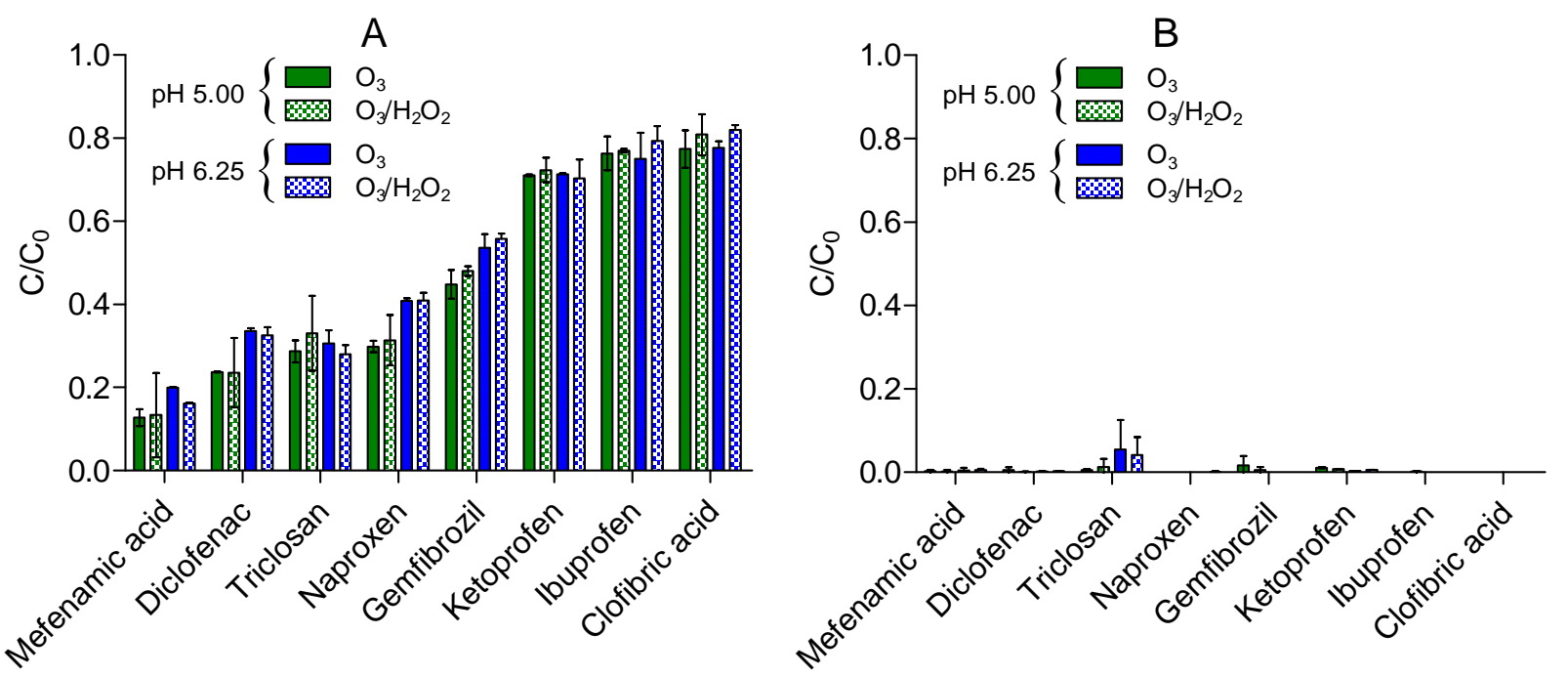

Figure 5 The normalized concentration of the 8 model pharmaceuticals after treatment with ozone and ozone/hydrogen peroxide at $\mathrm{pH} 5.00$ and $\mathrm{pH} 6.25$. A) Ozone dose $=2.9 \mathrm{mg} / \mathrm{L}$ and hydrogen peroxide dose $=0.28 \mathrm{mg} / \mathrm{L}$. B) Ozone dose $=18 \mathrm{mg} / \mathrm{L}$ and hydrogen peroxide dose $=1.8 \mathrm{mg} / \mathrm{L}$ (Temperature $\left.=15^{\circ} \mathrm{C}, \mathrm{DOC}=18 \mathrm{mg} / \mathrm{L}\right)$.

\section{Conclusions}

The findings can be summarized as:

- Increased DOC increased the required ozone dose for removal of a pharmaceutical in wastewater effluent.

- The ozone dose required for $90 \%$ removal of a pharmaceutical is compound specific and varies between $0.50 \pm 0.06 \mathrm{mg}-\mathrm{O}_{3} / \mathrm{mg}-\mathrm{DOC}$ (sulfadiazine) and $4.7 \pm 0.6 \mathrm{mg}-\mathrm{O}_{3} / \mathrm{mg}-\mathrm{DOC}$ (diatrizoic acid) for the investigated compounds.

- The $\mathrm{pH}$ of the wastewater is highly relevant, as a low $\mathrm{pH}$ will prolong the lifetime of the ozone drastically within the experimentally observed $\mathrm{pH}$ range for the investigated 
wastewater. For perspective the observed ozone lifetime at $\mathrm{pH} 7.75$ is $<1 \mathrm{~min}$ but about 10 min at $\mathrm{pH} 5.0$ thus potentially requiring a 10 -foldlarger reaction tank to avoid releasing ozone to the receiving water.

- If ozone lifetime is increased due to low $\mathrm{pH}$ a very low concentration of hydrogen peroxide can be added to markedly decrease the lifetime of the ozone without interfering with the effectiveness of removal of micro-pollutants.

- Increased $\mathrm{pH}$ resulted in increased ozone doses $\left(\mathrm{DDO}_{3}\right)$ required to remove any pharmaceutical.

\section{Acknowledgments}

The authors acknowledge MUDP (Miljøteknologisk Udviklings- og Demonstrationprogram) for funding of the MERMISS project (Miljøeffektiv rensning af højpotente lægemiddelstoffer i hospitalsspildevand - Environmentally effective removal of pharmaceuticals from hospital wastewater) and the AUFF grant "Advanced water purification using bio-inorganic nanocatalysts and soil filters" (http://waterpurification.au.dk/). The authors are also grateful to Kim Sundmark, (Kruger/Veolia Water Technologies) and the rest of the operation team for their support in operating the pilot plant.

\section{References}

[1] C.G. Daughton, I.S. Ruhoy, Environmental footprint of pharmaceuticals: the significance of factors beyond direct excretion to sewers., Environ. Toxicol. Chem. 28 (2009) 2495-2521. doi:10.1897/08-382.1.

[2] P. Falås, H.R. Andersen, A. Ledin, J. La Cour Jansen, Occurrence and reduction of pharmaceuticals in the water phase at Swedish wastewater treatment plants, Water Sci. Technol. 66 (2012) 783-791. doi:10.2166/wst.2012.243.

[3] B.I. Escher, R. Baumgartner, M. Koller, K. Treyer, J. Lienert, C.S. McArdell, Environmental toxicology and risk assessment of pharmaceuticals from hospital wastewater, Water Res. 45 (2011) 75-92. doi:10.1016/j.watres.2010.08.019.

[4] P. Verlicchi, M. Al Aukidy, E. Zambello, What have we learned from worldwide experiences on the management and treatment of hospital effluent? - An overview and a discussion on perspectives, Sci. Total Environ. 514 (2015) 467-491. doi:10.1016/j.scitotenv.2015.02.020.

[5] M.M. Huber, A. Göbel, A. Joss, N. Hermann, D. Löffler, C.S. McArdell, et al., Oxidation of pharmaceuticals during ozonation of municipal wastewater effluents: a pilot study., Environ. Sci. Technol. 39 (2005) 4290-9. http://www.ncbi.nlm.nih.gov/pubmed/15984812.

[6] C. Bahr, J. Schumacher, M. Ernst, F. Luck, B. Heinzmann, M. Jekel, SUVA as control parameter for the effective ozonation of organic pollutants in secondary effluent, Water Sci. Technol. 55 (2007) 267. doi:10.2166/wst.2007.418.

[7] K.M.S. Hansen, H.R. Andersen, A. Ledin, Ozonation of estrogenic chemicals in biologically treated sewage., Water Sci. Technol. 62 (2010) 649-657. doi:10.2166/wst.2010.919. 
[8] Y. Lee, U. von Gunten, Oxidative transformation of micropollutants during municipal wastewater treatment: comparison of kinetic aspects of selective (chlorine, chlorine dioxide, ferrate VI, and ozone) and non-selective oxidants (hydroxyl radical), Water Res. 44 (2010) 555-66. doi:10.1016/j.watres.2009.11.045.

[9] T.A. Ternes, J. Stüber, N. Herrmann, D. McDowell, A. Ried, M. Kampmann, et al., Ozonation: A tool for removal of pharmaceuticals, contrast media and musk fragrances from wastewater?, Water Res. 37 (2003) 1976-1982. doi:10.1016/S0043-1354(02)00570-5.

[10] M.G. Antoniou, G. Hey, S. Rodríguez Vega, A. Spiliotopoulou, J. Fick, M. Tysklind, et al., Required ozone doses for removing pharmaceuticals from wastewater effluents., Sci. Total Environ. 456-457 (2013) 42-9. doi:10.1016/j.scitotenv.2013.03.072.

[11] K.M.S. Hansen, H.R. Andersen, Energy Effectiveness of Direct UV and UV/H2O2 Treatment of Estrogenic Chemicals in Biologically Treated Sewage, Int. J. Photoenergy. 2012 (2012) 1-9. doi:10.1155/2012/270320.

[12] C. von Sonntag, U. von Gunten, Chemistry of Ozone in Water and Wastewater Treatment: From Basic Principles to Applications, 1st ed., IWA Publishing, 2012.

[13] M.M. Huber, S. Canonica, G.-Y. Park, U. von Gunten, Oxidation of Pharmaceuticals during Ozonation and Advanced Oxidation Processes, Environ. Sci. Technol. 37 (2003) 1016-1024. doi:10.1021/es025896h.

[14] U. von Gunten, Ozonation of drinking water: part I. Oxidation kinetics and product formation., Water Res. 37 (2003) 1443-67. doi:10.1016/S0043-1354(02)00457-8.

[15] K.H. Langford, K. V. Thomas, Determination of pharmaceutical compounds in hospital effluents and their contribution to wastewater treatment works, Environ. Int. 35 (2009) 766770. doi:10.1016/j.envint.2009.02.007.

[16] K.S. Le Corre, C. Ort, D. Kateley, B. Allen, B.I. Escher, J. Keller, Consumption-based approach for assessing the contribution of hospitals towards the load of pharmaceutical residues in municipal wastewater, Environ. Int. 45 (2012) 99-111. doi:10.1016/j.envint.2012.03.008.

[17] L.H.M.L.M. Santos, M. Gros, S. Rodriguez-Mozaz, C. Delerue-Matos, A. Pena, D. Barceló, et al., Contribution of hospital effluents to the load of pharmaceuticals in urban wastewaters: Identification of ecologically relevant pharmaceuticals, Sci. Total Environ. 461-462 (2013) 302-316. doi:10.1016/j.scitotenv.2013.04.077.

[18] U. Nielsen, C. Hastrup, M.M. Klausen, B.M. Pedersen, G.H. Kristensen, J.L.C. Jansen, et al., Removal of APIs and bacteria from hospital wastewater by MBR plus O 3, O3 + H2O2, PAC or ClO2, Water Sci. Technol. 67 (2013) 854-862. doi:10.2166/wst.2012.645.

[19] L. Kovalova, H. Siegrist, H. Singer, A. Wittmer, C.S. McArdell, Hospital wastewater treatment by membrane bioreactor: Performance and efficiency for organic micropollutant elimination, Environ. Sci. Technol. 46 (2012) 1536-1545. doi:10.1021/es203495d. 
[20] M. Escolà Casas, R.K. Chhetri, G. Ooi, K.M.S. Hansen, K. Litty, M. Christensson, et al., Biodegradation of pharmaceuticals in hospital wastewater by a hybrid biofilm and activated sludge system (Hybas), Sci. Total Environ. 530-531 (2015) 383-392. doi:10.1016/j.scitotenv.2015.05.099.

[21] H. Bader, J. Hoigné, Determination of ozone in water by the indigo method, Water Res. 15 (1981) 449-456. http://www.sciencedirect.com/science/article/pii/0043135481900543.

[22] M.G. Antoniou, H.R. Andersen, Comparison of UVC/S2O8 2- with UVC/H2O2 in terms of efficiency and cost for the removal of micropollutants from groundwater, Chemosphere. 119 (2015) S81-S88. doi:10.1016/j.chemosphere.2014.03.029.

[23] G. Hey, a. Ledin, J.L.C. Jansen, H.R. Andersen, Removal of pharmaceuticals in biologically treated wastewater by chlorine dioxide or peracetic acid, Environ. Technol. 33 (2012) 10411047. doi:10.1080/09593330.2011.606282.

[24] V.G. Samaras, N.S. Thomaidis, A.S. Stasinakis, G. Gatidou, T.D. Lekkas, Determination of selected non-steroidal anti-inflammatory drugs in wastewater by gas chromatography-mass spectrometry, Int. J. Environ. Anal. Chem. 90 (2010) 219-229. doi:10.1080/03067310903243936.

[25] M. Escolà Casas, R.K. Chhetri, G. Ooi, K.M.S. Hansen, K. Litty, M. Christensson, et al., Biodegradation of pharmaceuticals in hospital wastewater by staged Moving Bed Biofilm Reactors (MBBR), Water Res. 83 (2015) 293-302. doi:10.1016/j.watres.2015.06.042.

[26] Y. Lee, L. Kovalova, C.S. McArdell, U. von Gunten, Prediction of micropollutant elimination during ozonation of a hospital wastewater effluent, Water Res. 64 (2014) 134148. doi:10.1016/j.watres.2014.06.027.

[27] M.-O. Buffle, J. Schumacher, S. Meylan, M. Jekel, U. von Gunten, Ozonation and Advanced Oxidation of Wastewater: Effect of $\mathrm{O} 3$ Dose, $\mathrm{pH}$, DOM and HO•-Scavengers on Ozone Decomposition and HO• Generation, Ozone Sci. Eng. 28 (2006) 247-259. doi:10.1080/01919510600718825.

[28] Y. Lee, D. Gerrity, M. Lee, A.E. Bogeat, E. Salhi, S. Gamage, et al., Prediction of micropollutant elimination during ozonation of municipal wastewater effluents: Use of kinetic and water specific information, Environ. Sci. Technol. 47 (2013) 5872-5881. doi:10.1021/es400781r.

[29] M.-O. Buffle, J. Schumacher, E. Salhi, M. Jekel, U. von Gunten, Measurement of the initial phase of ozone decomposition in water and wastewater by means of a continuous quenchflow system: application to disinfection and pharmaceutical oxidation, Water Res. 40 (2006) 1884-94. doi:10.1016/j.watres.2006.02.026.

[30] E.C. Wert, F.L. Rosario-Ortiz, S.A. Snyder, Effect of ozone exposure on the oxidation of trace organic contaminants in wastewater, Water Res. 43 (2009) 1005-14. doi:10.1016/j.watres.2008.11.050. 
[31] F. Javier Benitez, J.L. Acero, F.J. Real, G. Roldán, Ozonation of pharmaceutical compounds: Rate constants and elimination in various water matrices, Chemosphere. 77 (2009) 53-9. doi:10.1016/j.chemosphere.2009.05.035.

[32] Y. Lee, U. von Gunten, Quantitative structure-activity relationships (QSARs) for the transformation of organic micropollutants during oxidative water treatment, Water Res. 46 (2012) 6177-95. doi:10.1016/j.watres.2012.06.006.

[33] X. Chen, J.L. Nielsen, K. Furgal, Y. Liu, I.B. Lolas, K. Bester, Biodegradation of triclosan and formation of methyl-triclosan in activated sludge under aerobic conditions, Chemosphere. 84 (2011) 452-456. doi:10.1016/j.chemosphere.2011.03.042.

[34] C. Zwiener, F.H. Frimmel, Oxidative treatment of pharmaceuticals in water, Water Res. 34 (2000) 1881-1885. doi:10.1016/S0043-1354(99)00338-3.

[35] M.G. Antoniou, H.R. Andersen, Evaluation of pretreatments for inhibiting bromate formation during ozonation., Environ. Technol. 33 (2012) 1747-53. doi:10.1080/09593330.2011.644586.

[36] G. Hey, S. Vega, J. Fick, M. Tysklind, A. Ledin, J. La Cour Jansen, et al., Removal of pharmaceuticals in WWTP effluents by ozone and hydrogen peroxide, Water SA. 40 (2014) 165. doi:10.4314/wsa.v40i1.20.

[37] S. Venditti, M. Arenz-Leufen, C. Köhler, K. Klepiszewski, A. Cornelissen, Treatment of pharmaceutical wastewaster by $\mathrm{O} 3$ and $\mathrm{O} 3 / \mathrm{H} 2 \mathrm{O} 2$ processes: a pilot scale study in Luxembourg, in: EcoTechnologies Wastewater Treat., IWA, Santiago de Compostela, Spain, 2012: pp.

https://www.researchgate.net/publication/260697444_Treatment_of pharmaceutical_wastew ater_by_O3_and_O3H2O2_processes_a_pilot_scale_study_in_Luxembourg. 


\section{Ozonation for source treatment of pharmaceuticals in hospital wastewater - ozone lifetime and required ozone dose}

Kamilla M. S. Hansen ${ }^{1}$, Aikaterini Spiliotopoulou ${ }^{2}$, Ravi Kumar Chhetri ${ }^{1}$, Mònica Escolà Casas ${ }^{3}$, Kai Bester ${ }^{3}$, Henrik R. Andersen ${ }^{*}$

1 Department of Environmental Engineering, Technical University of Denmark, Miljøvej 113, 2800 Kongens Lyngby, Denmark.*Corresponding author: Henrik@ndersen.dk

2 Water ApS, Farum Gydevej 64, 3520 Farum, Denmark

3 Department of Environmental Science, Aarhus University, Frederiksborgvej 399, 4000 Roskilde, Denmark

\section{Contents}

Supporting information

1 List of suppliers for pharmaceutical standards 2

2 Removal curves for pharmaceutical at different DOC levels..... 3

3 Half lifetime of ozone in wastewater effluent at different $\mathrm{pH}$ values.......................................5

4 Removal of pharmaceuticals by ozone at different $\mathrm{pH}$ values 6 


\section{List of suppliers for pharmaceutical standards}

Table S1. Suppliers of pharmaceutical standards for the 8 model compounds.

\begin{tabular}{|l|l|l|l|}
\hline Compound & CAS & Purity \% & Supplier \\
\hline Triclosan & $3380-34-5$ & $\geq 97$ & Sigma \\
\hline Mefenamic acid & $61-68-7$ & $\geq 98$ & Sigma \\
\hline Diclofenac sodium salt & $15307-78-6$ & & Sigma \\
\hline Naproxen & $22204-53-1$ & $\geq 98.5$ & Sigma-Aldrich \\
\hline Gemfibrozil & $25812-30-0$ & & Sigma \\
\hline Ketoprofen & $22071-14-4$ & $\geq 98$ & Sigma \\
\hline Ibuprofen & $15687-27-1$ & $\geq 98$ & Sigma \\
\hline Clofibric acid & $882-09-7$ & 97 & Aldrich \\
\hline Meclofenamic acid sodium salt & $6385-02-0$ & $\geq 98$ & Sigma \\
\hline Mecropop & $7085-19-0$ & Analytical standard & Riedek-de Haën \\
\hline
\end{tabular}




\section{Removal curves for pharmaceutical at different DOC levels}
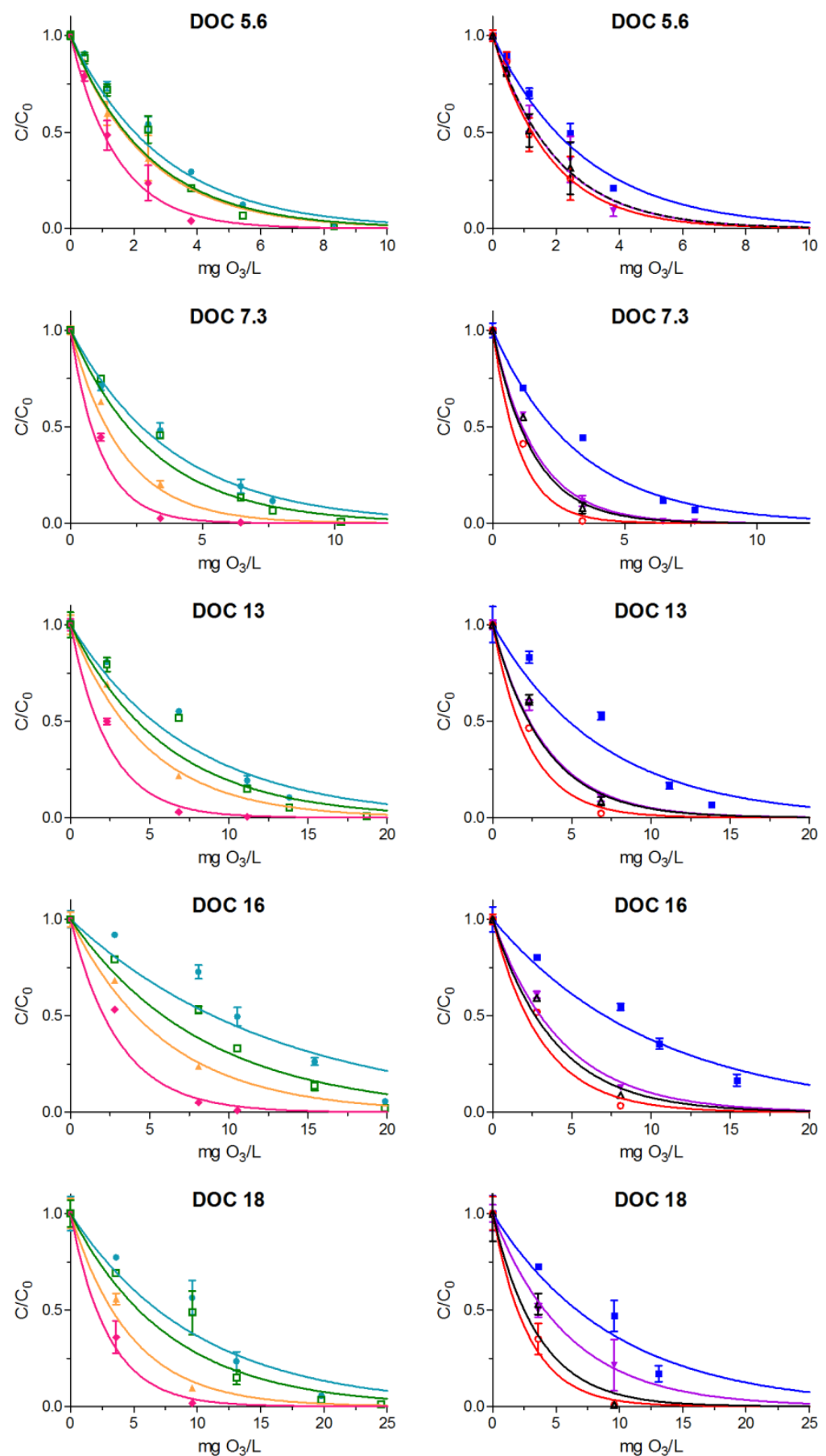

\begin{tabular}{|c|c|c|c|c|c|c|}
\hline Clofibric acid & $\bullet$ & Triclosan & $\mathbf{\square}$ & lbuprofen & 0 & Mefenamic acid \\
\hline Gemfibroz & 口 & Ketoprofen & $\nabla$ & Naproxen & $\Delta$ & Diclofenac \\
\hline
\end{tabular}

Figure S1 Removal of model compounds at 6 different ozone doses in effluent with different DOC content $\left(\right.$ Temperature $\left.=15^{\circ} \mathrm{C}\right)$. Error bars indicate standard deviation of triplicates. 

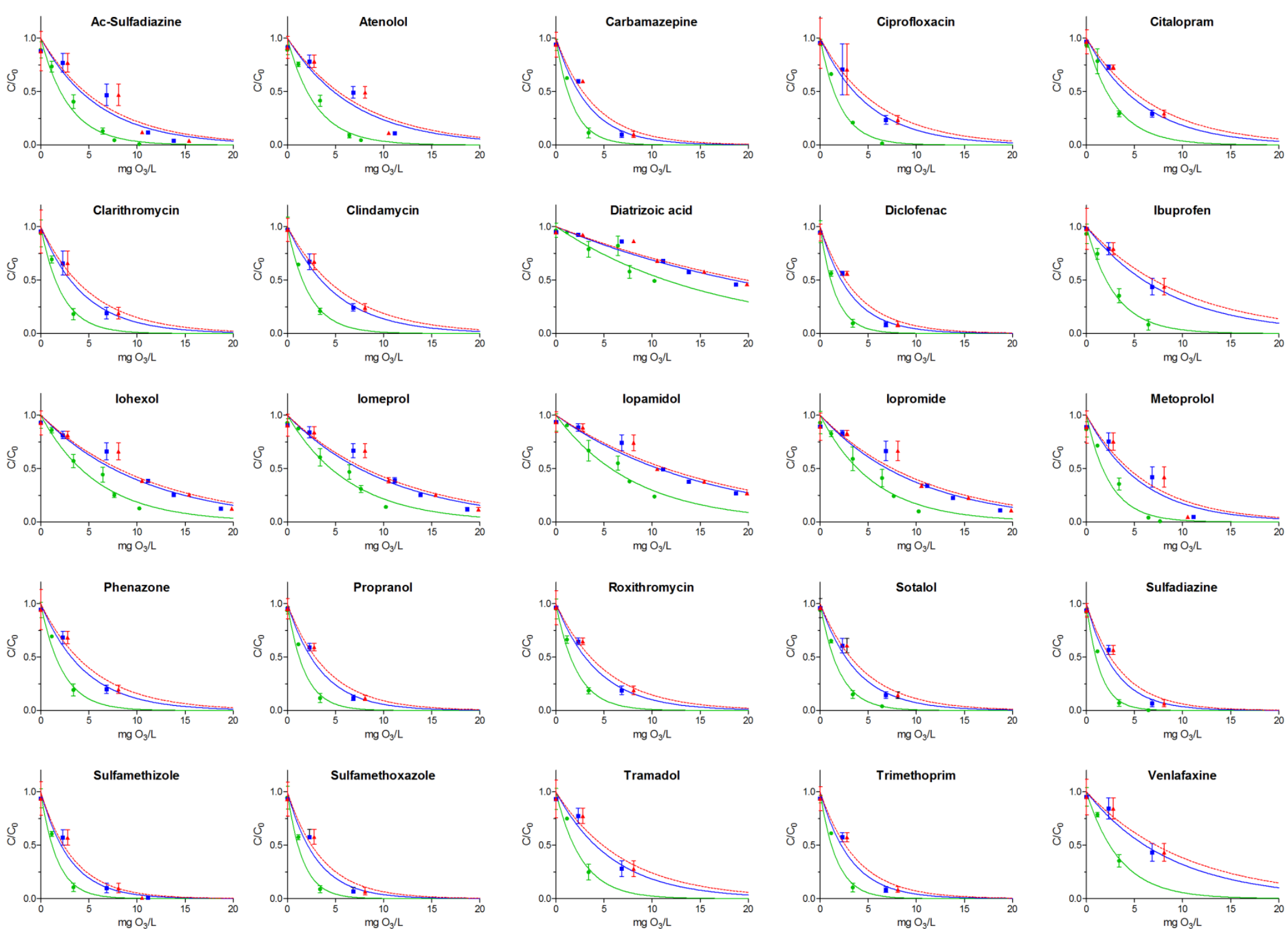

Figure S2: Removal of the treatment targets at 5 different ozone doses in 3 effluent with different DOC content (green $=7.3 \mathrm{mg}$ DOC/L, blue $=13 \mathrm{mg} \mathrm{DOC} / \mathrm{L}$ and red $=16 \mathrm{mg}$ DOC/L, temperature $=15^{\circ} \mathrm{C}$ ). Error bars indicates the standard deviation of duplicates. 


\section{Half lifetime of ozone in wastewater effluent at different $\mathrm{pH}$ values}

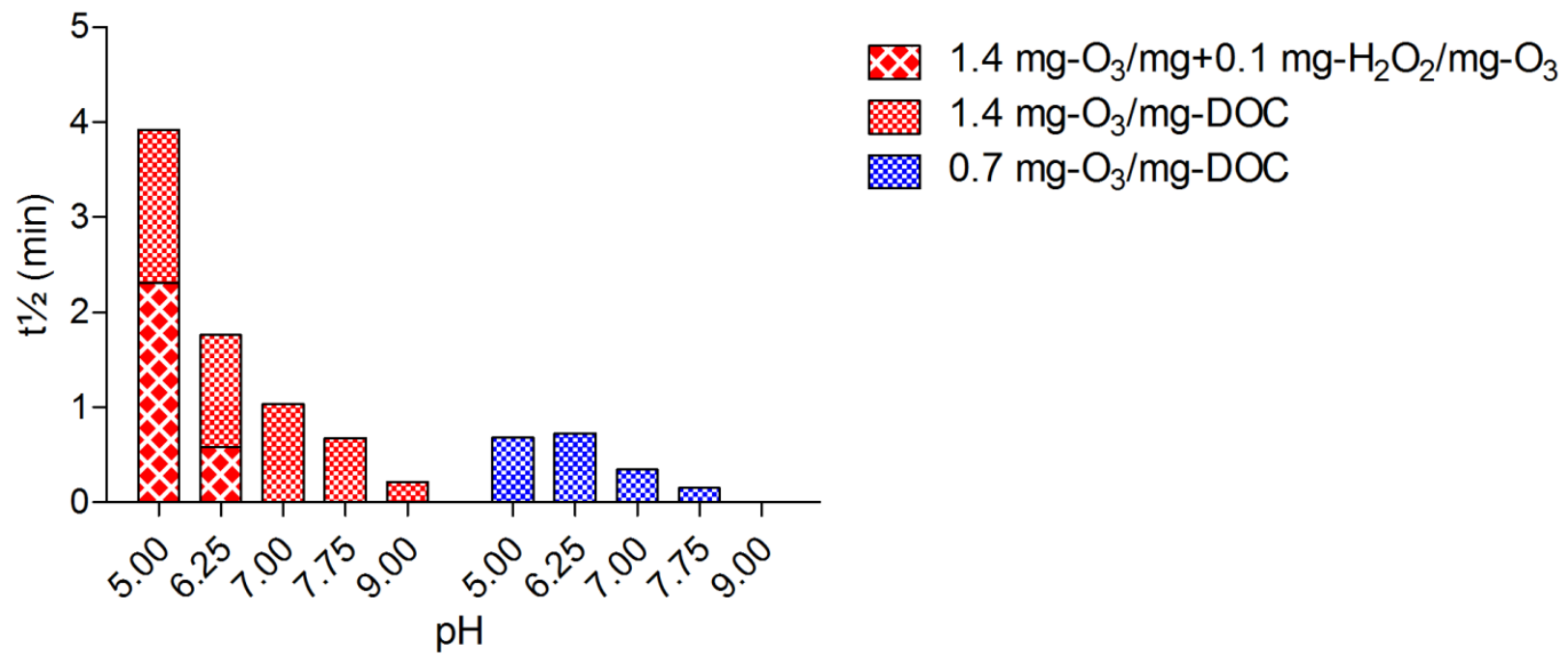

Figure S3: The half lifetime $\left(\mathrm{t}_{1 / 2}\right)$ of ozone at the $5 \mathrm{pH}$ values investigated (Temperature $=15{ }^{\circ} \mathrm{C}$, DOC $=18 \mathrm{mg} / \mathrm{L}$ ) 


\section{Removal of pharmaceuticals by ozone at different $\mathrm{pH}$ values}
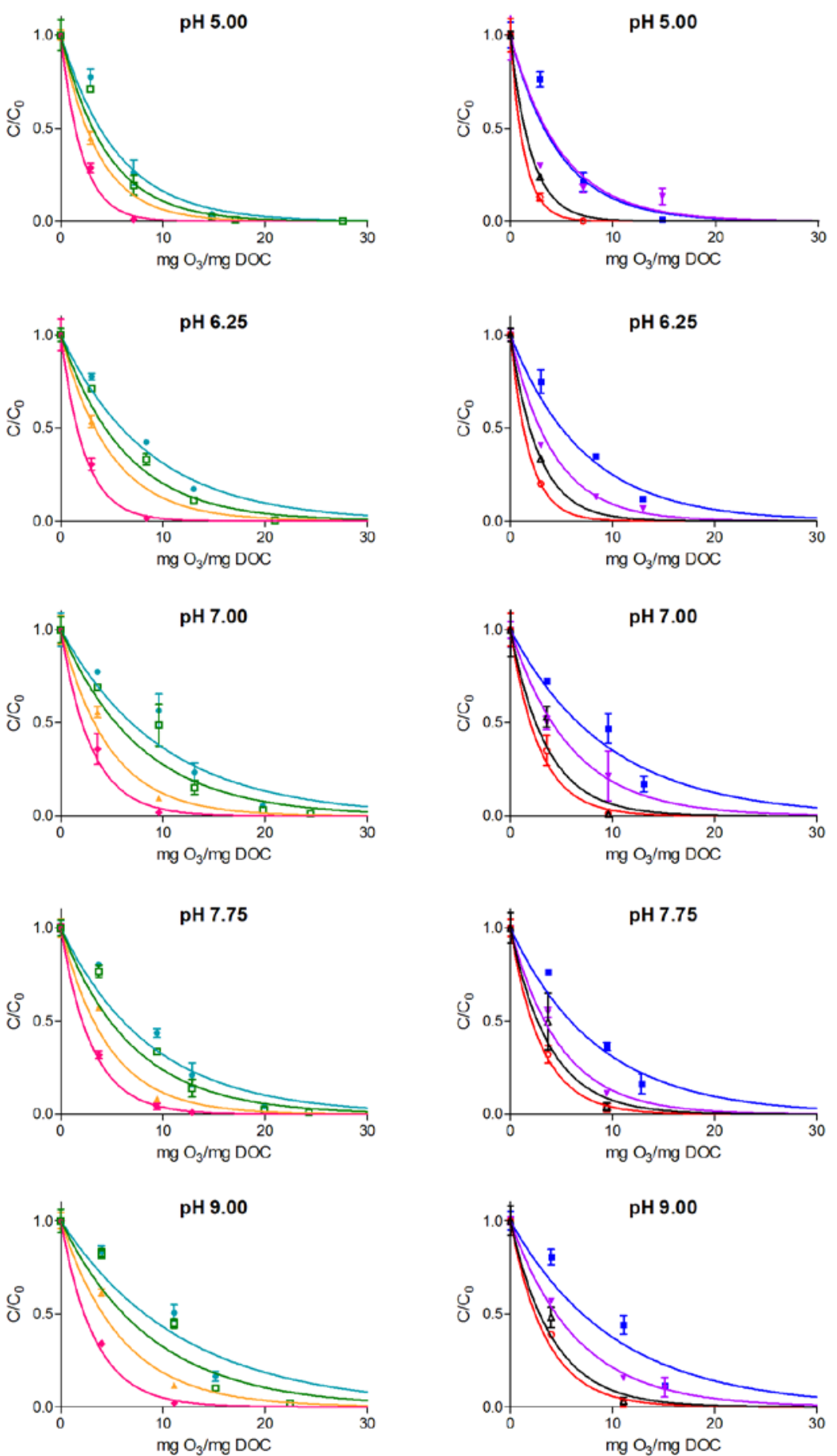

\begin{tabular}{|c|c|c|c|c|c|c|c|}
\hline$\bullet$ & Clofibric acid & $\bullet$ & Triclosan & a & lbuprofen & o & Mefenamic acid \\
\hline$\Delta$ & Gemfibrozil & 口 & Ketoprofen & $\boldsymbol{\nabla}$ & Naproxen & $\Delta$ & Diclofenac \\
\hline
\end{tabular}

Figure S4: Removal of the 8 model compounds at different ozone doses in effluent with different $\mathrm{pH}$ values $\left(\right.$ Temperature $\left.=15^{\circ} \mathrm{C}, \mathrm{DOC}=18 \mathrm{mg} / \mathrm{L}\right)$. 